\title{
Editorial
}

\section{Why Muslims Will Always Sacrifice Animals on the Eid}

Recently, blogger Anila Muhammad posted "Should Muslims Reconsider Animal Slaughter on Eid?" on the Canadian edition of the Huffington Post. ${ }^{1}$ She claims that some animal advocates are asking this question. Of course it is an activist's right to raise such an issue, even though it could be offensive to practicing Muslims. In reality, however, the majority of Muslims neither know of such a proposal, nor would they consider its possibility. Boldly claiming that some Muslims are calling "for an end to animal sacrifice," she cites these "notable animal advocates" and, full of passion and confidence, states that "many Muslims do not see the tradition of sacrifice to be serving 'their understanding of Islam." Intriguingly, she cites several Qur'anic verses and presents her own understanding of them - an understanding that happens to contrast sharply with the widely accepted narrative of Muslim scholars who base themselves on the Prophet's actual practice and understanding.

Although she presents the arguments from several perspectives (viz., intellectual, religious, social, and economic), I suggest that instead of "pretending" to know the Qur'an and Islamic worldview, she should have stuck with her activist perspective and thus avoided a response from Islamic intellectuals. But the way these activists keep citing the Qur' an to legitimize their arguments and claiming to know better what Muslims should do not only suggests little familiarity with Qur'anic content, but also exposes them to a rigorous and fair criticism from real scholars of the Qur'an and Islam.

To call for abandoning the ritual sacrifice or to challenge the Muslims' understanding of it, one has to go beyond the activist perspective and answer several specific questions, such as: Do God and the Prophet sanction this practice? How does Islam view eating meat? Does this tradition have any significant role in the hajj beyond symbolizing Abraham's sacrifice? Serious research would reveal the following answer: Until all Muslims simultaneously decide to abandon Islam (an impossibility), or until all animals become extinct, this ritual, especially during the hajj, will continue. 
The activists' argument is unsustainable for several reasons: They would be rejecting the Qur'anic verses dealing with the hajj and God's purpose for creating animals; challenging Abraham's understanding of his dream, which he thought was a revelation, as well as the Qur'an's narration of it; and challenging the Prophet's understanding and practice during the Eid and the hajj. Seeing the enormity of the above scenarios and their possible consequences, the activists seem to be dodging the real issues by shifting their blame to the Muslims' alleged "misunderstanding" of this particular tradition. But far from being part of the scholars' generations-long concoction or "misinterpretation," this tradition is a direct imitation of what the Prophet did during the Eid or while performing the hajj. People who want to accuse God (the Qur'an), Abraham, or the Prophet should state so and then justify their stance. I do not think that would be wise, especially if they claim to be Muslim.

\section{The Status of Animal Sacrifice in the Qur'an}

Animal sacrifice, so long as it is done to please God, endures because it is embedded in the Qur'an as a way of drawing closer to God and pleasing Him. However, quoting other activists, Anila Muhammad insists that "the largest contributing factor to why this ritual [of animal sacrifice] continues is the misinterpretation of the story of Abraham." First of all, that is absolutely incorrect, for other verses situate this ritual right in the middle of the larger hajj ritual. ${ }^{2}$

We have made [the slaughter of] camels [or cows: al-budn] part of God's sacred rites for you. There is much good in them for you. So invoke God's name over them as they are lined up for sacrifice; then, when they are fallen down dead, feed yourselves and those who do not ask, as well as those who do. We have subjected them to you (sakhkharnāha lakum) in this way so that you may be thankful." (Q. 22:36)

Even though the next verse states that God does not benefit from the animal's meat or blood, each Muslim must perform this sacrificial act in order for it to be considered done correctly and accepted. So to propose abandoning it is to suggest that Muslims stop worshipping God the way He requires.

The activists' also present a social and humanitarian argument: Rather than being "concerned with feeding people for a few days," Muslims could use the "money from this sacrifice and make other investments in our communities to help the disadvantaged." But one should not forget that the Qur'an calls for social justice and welfare while prescribing animal sacrifice. In fact, as seen above, such a sacrifice is an integral part of that social and humanitarian agenda. Some Muslim organizations (e.g., Islamic Relief, USA) ${ }^{4}$ are al- 
ready meeting these demands while observing this ritual, for they see it as complimentary to their humanitarian activities. In other words Muslims can perform both activities, for enabling the poor to eat meat is not only a social responsibility, but also a religious requirement.

The activists' proposal assumes that poor Muslims do not need the meat. However, some Muslims in South and Southeast Asia, not to mention Africa, subsist on it for weeks and months. Moreover, the staple foods of some poor Muslims do not provide the nutritional value found in meat or give them the pleasure that eating meat provides. Thus they look forward to the Eid for the entire year, mainly because they know they will have the opportunity to eat meat, even if only for one or several days. As strange as this may sound to affluent Muslims, especially those in the West, most of the world's poor ration the Eid meat for as long as they can. These are facts, not assumptions. I hope the activists are not arguing that poor Muslims should not be provided with better (or alternative) nutrition or a simple pleasure for even one day.

Second, it is either disingenuous or sheer ignorance to state that Abraham's story has been misinterpreted, unless one thinks he misunderstood his own dream (which the blogger seems to insinuate), did not actually have a dream, or had a dream that did not come from God (which the blogger clearly suggests). All of these possibilities are tantamount to challenging the Qur'an.

She bases this alleged misinterpretation on "at no point does the Qur'an state the dream was from God or that God demanded this sacrifice." Well, Islam considers the five daily prayers as more important than the sacrifice, even than the hajj of which it is part, and yet never tells Muslims to pray five times a day. So, can truly busy Muslims abandon or lower the number of prayers since praying five times would lower their productivity rate? Absolutely not. Yet while some Muslims may do so for such reasons (more conveniently in the West), they do not cite the lack of Qur'anic evidence.

Third, if God is not the source of Abraham's dream, then to whom does the repeated pronoun "we" refer?

WE called out to him, "Abraham! You have fulfilled the dream." This is how WE reward those who do good - it was clearly a test. And WE ransomed him [his son] with a momentous sacrifice, and WE let him be praised by succeeding generations. "Peace be upon Abraham." (Q. 37:104-09)

If there is any misunderstanding, it is obviously on her part. No experts of Arabic literature and/or principles of Qur'anic exegesis would make such a charge, because they are aware that Arabic literary sources, as well as the Qur'an, are replete with instances of $\bar{j} j \bar{a} z$ (brevity) - not to be confused with $i^{\prime} j \bar{a} z$ (inimitability) - a literary stylistic device that omits subjects and nouns 
or shortens statements due to the provision of sufficient clues, such as pronouns and contexts, that point to them. ${ }^{5}$

Experts do not need the Qur'an to state that "God commanded Abraham in a dream to sacrifice his son" to understand what this story means, just as Muslims do not necessarily need the Qur' an to spell out that they have to pray five time a day. There are different ways to convey these messages. In addition to the Prophet's own practice, ample clues make the Qur'an's intention very clear. To insist that the Qur'an clarify everything only betrays one's knowledge about it and Arabic stylistics. Of course activists have the right to press on with their agenda, and Muslims have the choice to accept or reject it. But the former have no right to impose it upon the Qur'anic text or Muslims, especially if they lack the necessary knowledge and expertise.

\section{Islam's View on Consuming Meat}

In Islam, consuming the meat of livestock is not only lawful and allowed, but is used both to prove God's grace and generosity to human beings and to attract their gratitude and appreciation to Him as the One who subjugated, subjected, and subdued (taskhir) animals of all kinds for the people's benefit: "Livestock animals are lawful as food for you..." (Q. 5:1;22:30). To challenge this position is to reject numerous Qur'anic verses to that effect.

First of all, the Qur'an expects Muslims to appreciate this concept of taskhi $r$, for "We have subjected them to you in this way so that you may be thankful" (Q. 22:36) as well as "And the livestock, He created them for you" (Q. 16:5). No matter how big, wild, or smart an animal is, it can be placed under human control for several purposes. This is expected to be appreciated as God's mercy toward humanity, not as an injustice or mistreatment of animals. Despite this truth, however, there will always be people who will abuse animals - and Islam prescribes harsh punishments for them.

Second, aside from religious rites, God has subjected animals so that they will benefit humanity via consumption (Q. 6:142; 23:21; 40:79) and drinking (Q. 16:66; 23:21); riding (Q. 23:22; 43:12-13; 40:79) and travel (Q. 40:80); recreation, decoration, and adornment (Q. 16:80); carrying cargo (Q. 6:142; 40:80); providing warmth and heat, amusement and entertainment; and other benefits. Most of the purposes are stated in the following verses:

And the livestock, He created them for you. You derive warmth and other benefits from them; and you eat from their meat. And you find beauty in them when you bring them home to rest and when you drive them out to pasture. They also carry your loads to lands you yourselves could not reach 
without great hardship. Truly your lord is kind and merciful. Horses, mules, and donkeys [He created] for you to ride and use for show, and He creates other things you know nothing about. (Q. 16:5-8)

It is God who has given you a place of rest in your homes and from the skins of animals made you [tent] homes that you find light [to handle] when you travel and when you set up camps, and from their wool, fur, and hair [He made] furnishing and comfort for a while. (Q. 16:80)

As some of these benefits may be achieved through lovingly grooming and carefully keeping the animals alive, most of them can only be fulfilled via the compassionate slaughter ritual that Islam demands. Admittedly, there are modern and convenient ways to accomplish some of these purposes without having to use animals at all, and Muslims who can afford to make use of them gladly do so. But as for those to whom animals remain indispensable, Islam encourages them to avail themselves of the animals provided and thank God. Thus Muslims should not apologize for slaughtering animals; rather, they should thank God for allowing them to do so humanely.

The main point here is that Islam permits the use of animals for such benefits not out of cruelty, but to exhibit God's mercy, serve as a lesson, and elicit thanks. If some Muslims sincerely feel bad for slaughtering animals or consuming animal products, they have the freedom not to do so. However, activists cannot argue that all Muslims should stop eating meat just because of their feelings about this issue.

If one wants to be candid about the call for Muslims to stop slaughtering animals, one would see this as an extension of western cultural imperialism. This is not to say that all westerners support the activists' position or that there are no non-western voices on this account. Rather, it is to assert that advocating that a particular Muslim practice be changed or to convince the world to give up eating meat in general is rooted in recent western culture, which seems to have an utter disregard for all other cultures as it is imposed on them. This is particularly true when one realizes that this view did not even represent western culture until recent decades.

\section{This Issue}

We begin the first issue of 2013 with Auwais Rafudeen's “Asad on the Secular: Implications for South Africa's Muslim Marriages Bill Debate.” Rafudeen probes this ongoing debate in the light of anthropologist Talal Asad's critique developed in his Formations of the Secular (2003). He approaches the debate under four Asadian themes, while arguing that there are inevitable nuances 
when applying these ideas to the South African context. Next is Luqman Zakariyah's "Textuality as a Linguistic Mechanism for Codifiying Legal Maxims in Islamic Criminal Law." The author examines the use of textuality as a linguistic mechanism to complement the juristic methodology of codifying legal maxims ( qawä'id al-fiqhìah) from Qur'anic exegesis. He concludes that the remit of legal maxims codified from textual revelations can be done either directly or indirectly.

"The Authority of the Sunnah According to the Qur'anic Text" is penned by Ahmad Eldridge Cleaver. Through thirty-five Qur'anic verses that talk about Muhammad, Cleaver analyzes what the Qur'an ascribes to the Sunnah and highlights the existence of clues within the text as to the Sunnah's significance, role, and legal authority. We close with "A Third Sector-Led Economic Model: Scopes of Islamic Entrepreneurship" by Rafiqul Islam Molla and Md. Mahmudul Alam. The authors focus on the theory of an Islamic style of entrepreneurship and offer two examples from Bangladesh and one from Malaysia. They contend that this style is the most efficient and desirable one for effectively widening and mainstreaming community-centric third sector economics.

I hope our readers find these papers not only thought-provoking and stimulating, but also sources of inspiration and motivation for their own research.

\section{Endnotes}

1. Anila Muhammad. "Should Muslims Reconsider Animal Slaughter on Eid?" http://www.huffingtonpost.ca/anila-muhammad/animal-muslim-eid_b_ 1971072.html (Retrieved 11/24/12).

2. I have cited the raw Qur'anic verses without any reference to classical or modern Muslim exegesis. Seeing that activists have no appreciation for Muslim scholarship, I did not want them to accuse me or any Qur'anic commentator of misinterpreting or manipulating any verse. Otherwise, it is advisable to consult the authentic Qur'an commentaries of al-Tabari, al-Qurtubi, al-Razi, Ibn Ashur, alTabataba'i, and others for more information.

3. Other verses include earlier ones in the same chapter, such as Q. 22:28 and 34.

4. http://www.irusa.org/islamic-relief-usa/ and http://www.irusa.org/campaigns/udhiyah-qurbani.

5. For more on $\bar{j} j \bar{a} z$ in the Qur'an, see, Badr al-Din al-Zarkashi, Al-Burhān fì 'Ulüm al-Qur'ān (Beirut: Dar al-Kutub al-'Ilmiyyah, 1988); Jalal al-Din al-Suyuti, $A l$ Ițqān fì 'Ulüm al-Qur'ān (Cairo: Dar al-Hadith, 2006), vols. 1-2. 